\title{
Inventarisasi Tumbuhan Paku di Jalur Ciwalen Taman Nasional Gunung Gede Pangrango, Jawa Barat
}

\author{
IBRAHIM FATAHILLAH ${ }^{1}$, INDRI FAJAR LESTARI ${ }^{1}$, KHAIRUNNISA SALSABILA ${ }^{1}$, RATNA \\ PRATIWI $^{1}$, TASYA AMALIA ${ }^{1}$, ARI SEPTIYANINGSIH ${ }^{1}$, UMI KULSUM ${ }^{1}$, RIZHAL HENDI \\ RISTANTO $^{1}$, AGUNG SEDAYU $^{1}$ \\ ${ }^{1}$ Pendidikan Biologi, Fakultas Matemtika dan Ilmu Pengetahuan Alam \\ Universitas Negeri Jakarta (UNJ) \\ Jl. Pemuda 10, Rawamangun, Jakarta Timur, DKI Jakarta. 13220 \\ Email: rararatnapratiwi66@gmail.com
}

Received 4 January 2018; Received in revised form 30 January 2018;

Accepted 2 March 2018; Available online 9 May 2018

\begin{abstract}
After being observed as a whole, Gunung Gede Pangrango National Park has a high diversity of Ferns. This research aims to describe ferns in the Ciwalen Gunung Gede Pangrango National Park, so it is hopefully could describe the diversity of ferns in that path. The Inventory of ferns is done by using exploration method with random sampling technique which then identified with General Key to Malayan Fern referral. The results of this research showed that there are ten types of ferns that have been founded in the Ciwalen Gunung Gede Panggrango National Park, such as Sphaerostephanos sp., Asplenium truncata, Nephrolepis davallioides, Botrychium daucifolium, Selaginella opaca, Huperzia phlegmaria, Equisetum ramosissimum, Didymochlaena truncatula, Hymenophyllum sp., and Diplazium poliferum. Features any distinctive Ferns can be seen from the form such as rhizome, type of frond, an accessory, the sorus, habitats that were found and others.
\end{abstract}

Keywords: fern, inventory, TNGGP.

\section{INTISARI}

Setelah diamati secara keseluruhan, Taman Nasional Gunung Gede Pangrango ini memiliki keanekaragaman paku yang cukup tinggi. Penelitian ini bertujuan untuk mendeskripsikan tumbuhan paku di Jalur Ciwalen Taman Nasional Gunung Gede Panggrango, sehingga diharapkan dapat menggambarkan keanekaragaman tumbuhan paku di jalur tersebut. Inventarisasi tumbuhan paku dilakukan dengan cara metode eksplorasi dengan teknik random sampling yang selanjutnya diidentifikasi dengan rujukan General Key to Malayan Fern. Hasil penelitian menunjukkan terdapat sepuluh jenis paku yang ditemukan di Jalur Ciwalen Taman Nasional Gunung Gede Panggrango, yaitu Sphaerostephanos sp., Asplenium truncata, Nephrolepis davallioides, Botrychium daucifolium, Selaginella opaca, Huperzia phlegmaria, Equisetum ramosissimum, Didymochlaena truncatula, Hymenophyllum sp. dan Diplazium poliferum. Ciri khas setiap tumbuhan paku dapat dilihat dari bentuk morfologi yaitu bentuk rhizome, tipe frond, aksesori, letak sorus, habitat ditemukan dan lain-lain.

Kata Kunci: paku, inventarisasi, TNGGP.

\section{PENDAHULUAN}

Taman Nasional Gunung Gede Pangrango (TNGGP) mempunyai peranan yang penting dalam sejarah konservasi di Indonesia. Pada tanggal 6 Maret 1980 Menteri Pertanian melaui SK Menteri Pertanian No.
36/Mentan/X/1982, menetapkan bahwa kawasan Gunung Gede Pangrango dengan luas 15.196 Ha termasuk cagar alam, hutan alam, dan taman hutan disekitarnya adalah Kawasan Taman Nasional. Untuk meningkatkan luas kawasan konservasi, pada tahun 2003 melalui 
SK Menteri Kehutanan No. 174/KPTS-II/2003 dilakukan perluasan dari $15.196 \mathrm{Ha}$ menjadi $21.975 \mathrm{Ha}$.

Pterydophyta atau tumbuhan paku merupakan salah satu kelompok flora Indonesia yang memiliki keragaman tinggi serta persebaran yang luas. Pteridophyta dapat dijumpai di daerah tropis maupun subtropis, di ketinggian yang berbeda, hidup di tanah atau menumpang pada pohon. Pteridophyta tersebar sebanyak 450 spesies di Jawa Barat, 333 spesies di Jawa Tengah, dan 319 spesies di Jawa Timur (Jamsuri et al., 2007)

Gunung Gede dan Pangrango merupakan alur gunung berapi yang terbentuk dari aktivitas lapisan kulit bumi secara terus menerus. Secara umum batuan pada kawasan ini terdiri dari batuan vulkanik (Mota, 2002). Ketinggian Gunung Gede (2958 m dpl) dan Gunung Pangrango (3019 m dpl).

Kawasan Taman Nasional Gunung Gede Pangrango adalah kawasan perlindungan (save $i t$ ), kajian ilmiah (study it) dan pemanfaatan yang lestari (use it). Pengembangan Tumbuhan Paku di kawasan ini dikelola oleh Balai Besar Konservasi dan Sumber Daya Alam Jawa Barat, Balai Besar Taman Nasional Gunung Gede Pangrango, LIPI, dan PusLitBangHut Konservasi Alam.

TNGGP merupakan daerah beriklim tropis dengan curah hujan berkisar antara 3000-4000 $\mathrm{mm} /$ tahun. Berdasarkan klasifikasi Schmidt dan Ferguson tipe iklim kawasan ini termasuk tipe iklim A. Temperatur di Cibodas antara 18$10^{\circ} \mathrm{C}$ pada siang hari dan malam hari berkisar $0-5{ }^{\circ} \mathrm{C}$. Kelembaban udara berkisar antara 80$90 \%$, dan di daerah ini bertiup angin munson. Sistem hidrologi TNGGP ini terdiri dari sungai sungai yang umumnya membentuk pola radial, dan laju aliran relatif stabil (Mota, 2002). Kawasan ini merupakan pemasok air yang banyak, terihat dari debit air sekitar 8 milyar liter per tahun (Hartono, 2008)

Sebagai tumbuhan tingkat rendah, namun sekelompok tumbuhan ini telah memiliki sistem pembuluh sejati (kormus) tetapi tidak menghasilkan biji untuk reproduksinya. Alihalih biji, kelompok tumbuhan ini masih menggunakan spora sebagai alat perbanyakan generatifnya, sama seperti lumut dan fungi (Smith et al., 2006).

Alat perkembangbiakan tumbuhan paku yang utama adalah spora. Jadi penempatan tumbuhan paku ke dalam golongan tingkat rendah atau tinggi bisa berbeda-beda tergantung sifat yang digunakan sebagai dasar. Jika didasarkan pada macam alat perkembangbiakannya, maka sebagai tumbuhan berspora tergolong tumbuhan tingkat rendah. Namun, jika didasarkan pada ada atau tidaknya sistem pembuluh, tumbuhan paku dapat digolongkan sebagai tumbuhan tingkat tinggi karena sudah mempunyai berkas pembuluh (Tjitrosoepomo et al., 1998).

Di dalam kehidupannya, tumbuhan paku dipengaruhi oleh faktor lingkungan. Setiap jenis tumbuhan paku memerlukan kondisi lingkungan abiotik untuk dapat hidup. Tumbuhan ini hidup subur dan banyak dijumpai pada lingkungan yang lembab dan beriklim tropis (Sastrapradja et al., 1979)

Indonesia memiliki jumlah Pteridophyta yang melimpah karena Indonesia memiliki iklim yang mendukung pertumbuhan Pteridophyta. Pteridophyta banyak ditemukan pada hutan tropika yang memiliki cahaya matahari melimpah dan kelembaban tinggi. Di hutan tropika Pteridophyta menempati habitat yang ternaungi seperti epifit pada pepohonan atau pada dasar lantai hutan yang lembab, Pteridophyta di hutan terlindung dari panas dan angin kencang. Beberapa jenis Pteridophyta dapat di temukan di lahan terbuka membentuk belukar yang menutupi tanahtanah kosong. Pteridophyta di lahan terbuka kebanyakan hidup soliter dan tumbuh lebih lambat dari Pteridophyta di daerah ternaungi (LIPI, 1980). Sebelum penulisan artikel ini, telah dilakukan pengamatan mengenai tumbuhan paku dan kerabatnya serta belajar bagaimana cara mengidentifikasinya dan mengenal spesies tumbuhan paku dengan cara mendeskripsikan ciri-ciri spesies tersebut dengan panduan kunci determinasi dan field guide. Pengamatan dilakukan di salah satu jalur pendakian yaitu jalur Ciwalen.

\section{METODE}


Lokasi dan Waktu Penelitian. Penelitian ini dilakukan pada tanggal 4 November 2017 di Jalur Ciwalen, Taman Nasional Gunung Gede Pangrango, Jl. Raya Cibodas, Cipanas,
Cianjur, Jawa Barat. Secara geografis Taman Nasional Gunung Gede Pangrango (TNGGP) terletak antara $106051^{\circ}-107002^{\circ} \mathrm{BT}$ dan $6041^{\circ}-6051^{\circ} \mathrm{LS}$.
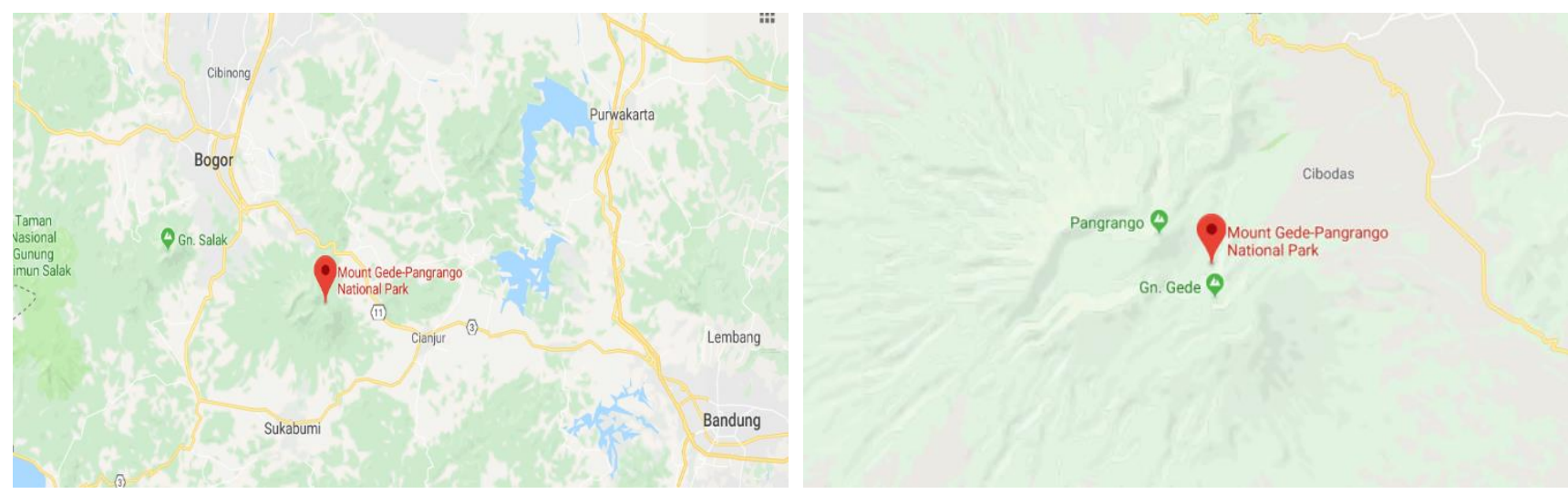

Gambar 1. Lokasi penelitian di Taman Nasional Gunung Gede Pangrango (http://www.google.co.id/maps/)

Alat-alat yang digunakan adalah alat tulis, kamera, buku, meteran jahit, penggaris, plastik spesimen, papan jalan, lembar tabulasi data, jam tangan, dan field guide.

Metode yang digunakan adalah metode eksplorasi sehingga tidak membuat transek. Pengambilan sampel dilakukan dengan teknik random sampling karena pada penelitian ini tidak ada kriteria spesifik tumbuhan paku yang akan diteliti. Eksplorasi dilakukan di sepanjang jalur yang sudah tersedia yaitu di Jalur Ciwalen. Setelah pengambilan sampel, tumbuhan paku yang didapat kemudian diidentifikasi dengan rujukan buku identifikasi General Key to Malayan Fern (Holtum, 1996) dan kunci identifikasi paku.

\section{HASIL}

Tabel 1. Tumbuhan paku yang ditemukan di lokasi penelitian

\begin{tabular}{ll} 
No. & \multicolumn{1}{c}{ Klasifikasi } \\
\hline 1. & $\begin{array}{l}\text { Kelas : Polypodiopsida } \\
\text { Bangsa: Ophioglossales } \\
\text { Suku : Ophioglossaceae } \\
\text { Marga : Botrychium } \\
\text { Jenis : Botrychium } \\
\text { daucifolium Hook \& Grev } \\
\text { (PPG, 2016) }\end{array}$ \\
\end{tabular}




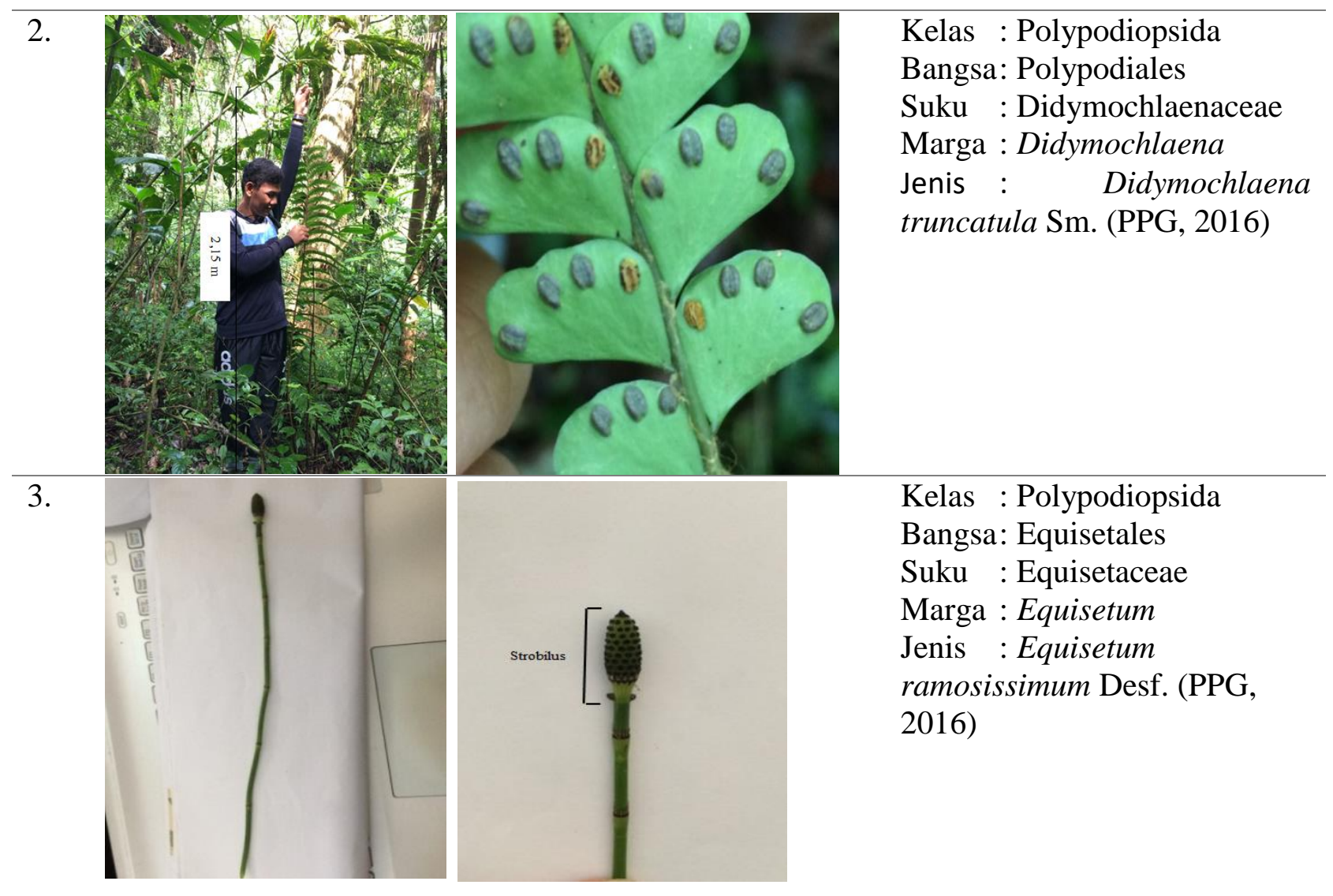

\section{4.}
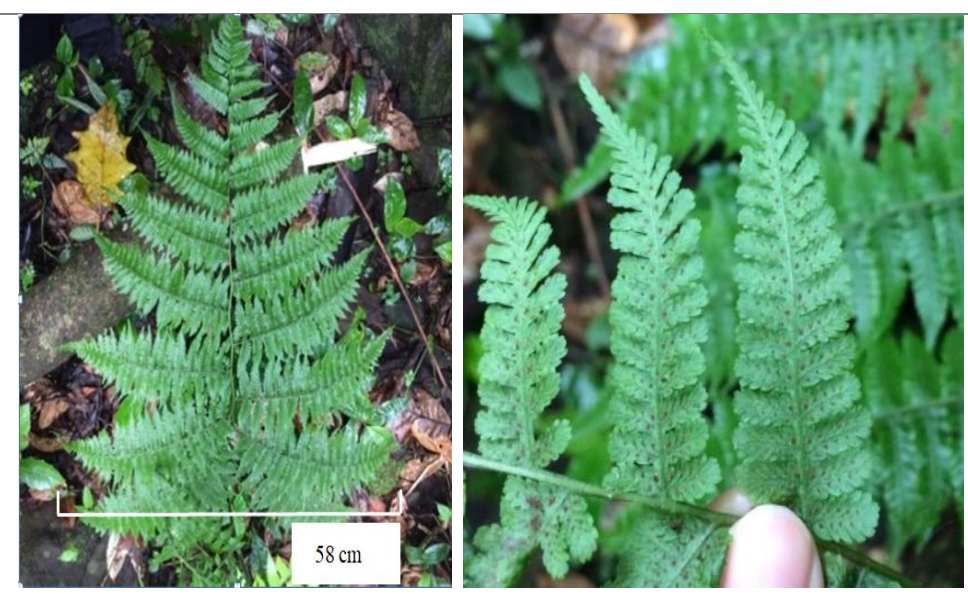

5.
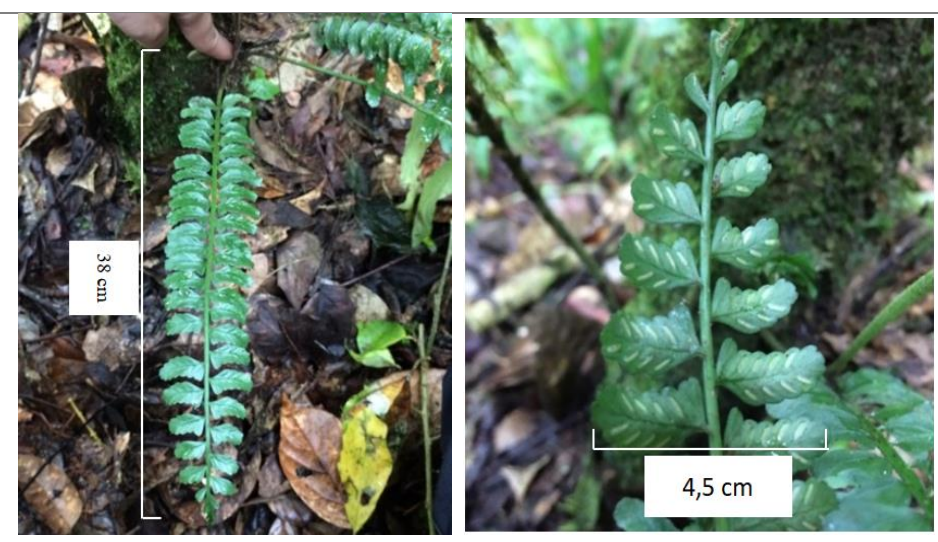

Kelas : Polypodiopsida

Bangsa: Polypodiales

Suku : Thelypteridaceae

Marga : Sphaerosthepanos

Jenis : Sphaerosthepanos sp.

(www.Gbif.org)

Kelas : Polypodiopsida

Bangsa: Polypodiales

Suku : Aspleniaceae

Marga : Asplenium

Jenis : Asplenium truncatum

C. (www.Gbif.org) 

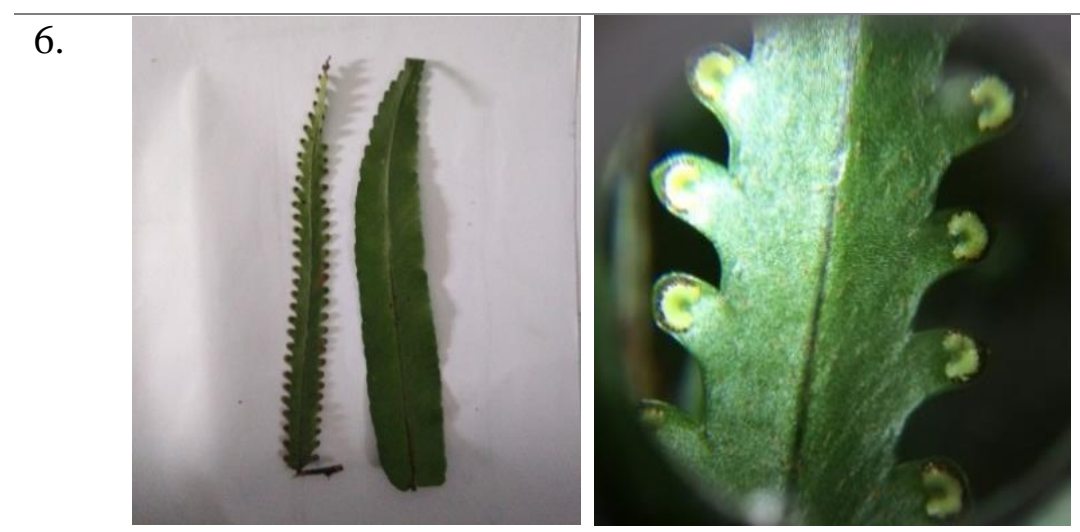

Kelas : Polypodiopsida

Bangsa: Polypodiales

Suku : Nephrolepidaceae

Marga : Nephrolepis

Jenis : Nephrolepis

davallioides Kze.

(www.Gbif.org)

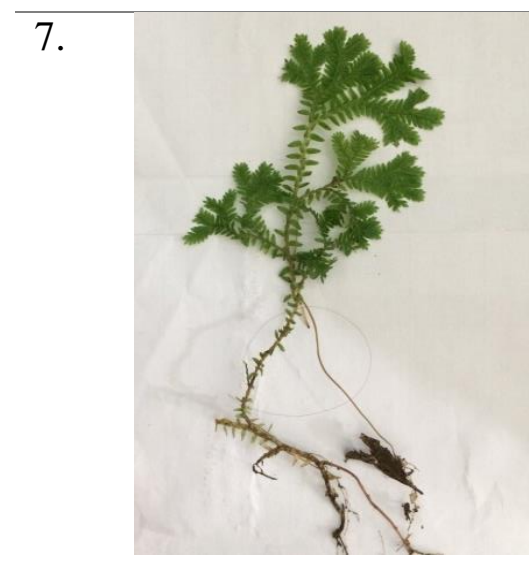

Kelas : Lycopodiopsida

Bangsa: Selaginellales

Suku : Selaginellaceae

Marga : Selaginella

Jenis : Selaginella opaca

Warb. (www.Gbif.org)

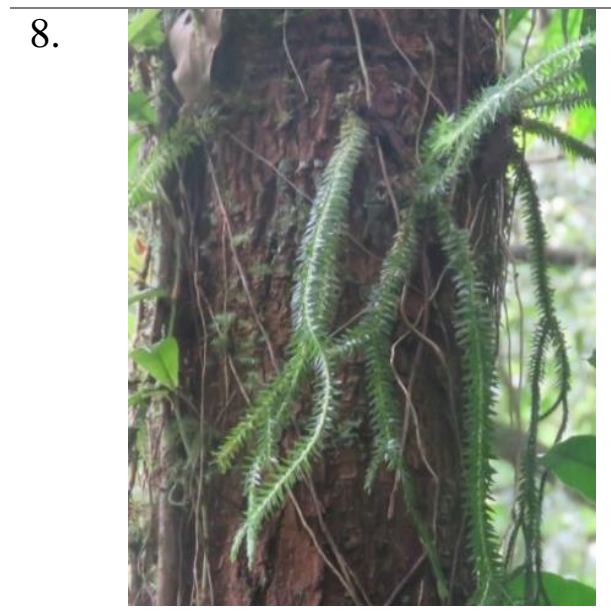

Kelas : Lycopodiopsida

Bangsa: Lycopodiales

Suku : Lycopodiaceae

Marga : Huperzia

Jenis : Huperzia phlegmaria

Rothm. (www.Gbif.org)

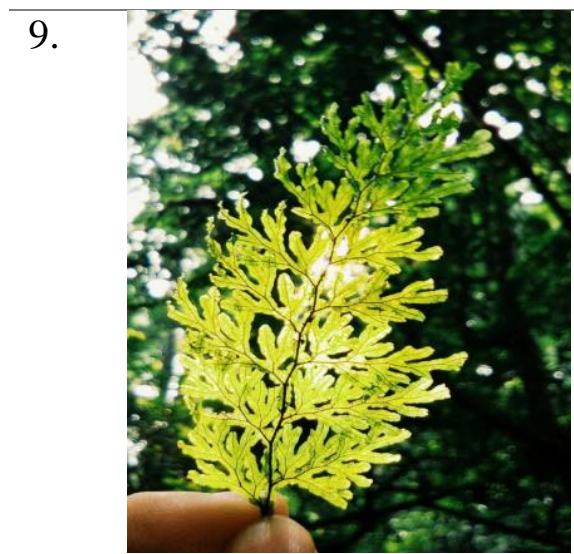

Kelas : Polypodiopsida

Bangsa: Hymenophyllales

Suku : Hymenophyllaceae

Marga : Hymenophyllum

Jenis : Hymenophyllum sp.

(www.Gbif.org) 


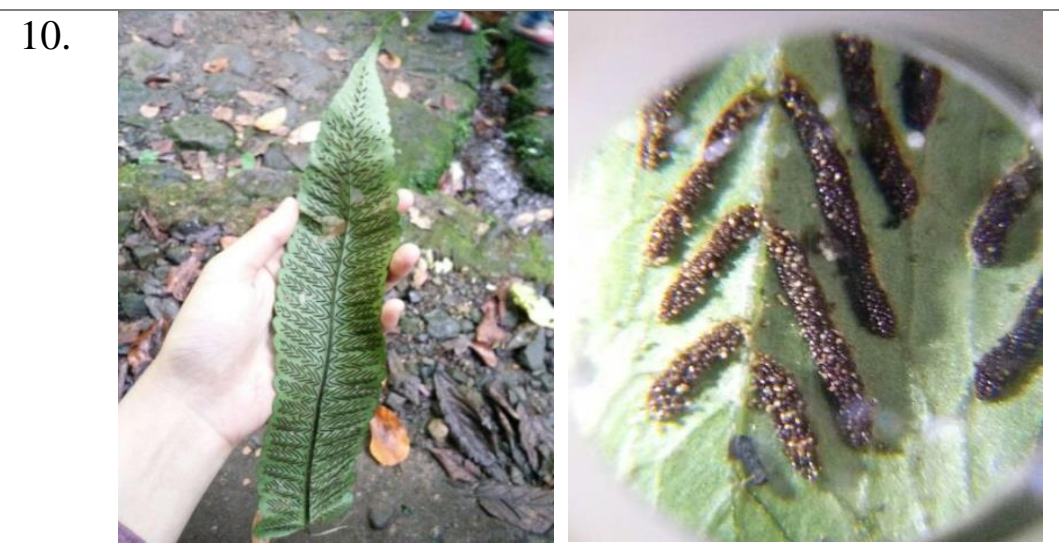

Kelas : Polypodiopsida

Bangsa: Polypodiales

Suku : Athyriaceae

Marga : Diplazium

Jenis : Diplazium proliferum

Thou. (www.Gbif.org)

\section{PEMBAHASAN}

Botrychium daucifolium Hook \& Grev. Ditemukan di Jalur Ciwalen Hm 08 Menurut pengamatan Botrychium daucifolium hidup secara terrestrial. Memiliki panjang $21 \mathrm{~cm}$ dan lebar $14 \mathrm{~cm}$. Setelah diamati, stipe dari Botrychium daucifolium ditutupi rambut. Memiliki lamina majemuk dan tidak berambut. Menurut literatur, tangkai daun yang fertil bercabang-cabang, bagian daun yang fertil itu berbentuk malai atau bulir dan keluar dari tangkai, dari pangkal, dari tengah, atau dari tepi daun yang steril. Sporangium tersusun dalam dua baris sepanjang cabang -cabangnya. Bagian daun steril menyirip 1-4 kali, dengan tulang-tulang daun yang menggarpu. Hidup terrestrial (di tanah). Sporangium besar, hampir bulat, tidak mempunyai annulus, dinding kuat, membuka dengan suatu retak melintang atau membujur (Tjitrosoepomo, et al., 1998).

Didymochlaena truncatula Sm. Ditemukan di Jalur Ciwalen Hm 06 dan hidup terrestrial. Setelah diamati rhizome nya longcreeping. Stipe dan rachis terdapat rambut. Lamina bipinnatus dengan bentuk pinna dimidate. Spora dilindungi indusium berbentuk kapsul. Menurut literatur, Didymochlaena truncatula hidup Terestrial dengan rhizome berdiameter $2,5 \mathrm{~cm}$, tegak, membentuk caudex berkayu pendek setinggi $20 \mathrm{~cm}$ dan berdiameter $15 \mathrm{~cm}$ dengan warna coklat tua. Frond berumbai, dengan tinggi 0,72,1 $\mathrm{m}$ dan melengkung. Lamina berbentuk lonjong-oval dengan bentuk pinna 2-pinnate, Indusium berwarna coklat gelap dengan batas yang lebih pucat, dengan tangkai memanjang yang sangat sempit, lebar berbentuk bulat panjang.

Equisetum ramosissimum Desf. Berdasarkan pengamatan Equisetum ramosissimum memiliki daun yang tereduksi. Memiliki stipe yang berongga (aerial). Sorusnya menyerupai strobilus. Di setiap nodus dapat hidup individu yang baru. (Tjitrosoepomo, 2014). Menurut Literatur, Equisetum merupakan tanaman terestrial. Memiliki akar yang keluar dari stolon. Diameter akar sekitar 3-6mm. Equisetum memiliki batang yang tegak, maksimal setinggi $1,5 \mathrm{~m}$ dengan diameter $5 \mathrm{~mm}$. Batangnya memiliki sendi-sendi yang sebenarnya merupakan meristem interkalar. Pada tiap sendinya terdapat 20-21 mikrofil yang mengelilinginya. Daun-daun tersebut sangat kecil ukurannya karena tereduksi. Sporanginya membentuk strobillus pada batang induk dan cabang utama. Ukuran strobillus bisa mencapai panjang $18 \mathrm{~mm}$ dan lebar $5 \mathrm{~mm}$. Masing-masing sporangiophore mengandung 6-9 sporangia. Spora Equisetum berbentuk bulat atau spheroidal (Holtum, 1966).

Sphaerosthepanos sp. Ditemukan di $\mathrm{Hm}$ 0 , sebelum sungai, tumbuh terrestrial. Panjang: $100 \mathrm{~cm}$, lebar: $58 \mathrm{~cm}$. Rhizomenya creeping, memiliki lebar $4 \mathrm{~cm}$. Stipe dan rachis nya bersisik. Lamina bipinnatus pinnatifit, percabangannya alternate (bersilangan). Di bagian costae pinna adaksial dan abaksial terdapat sisik. Menurut literatur rhizome nya setinggi $30 \mathrm{~cm}$ atau lebih tinggi dengan lanceolate coklat tua, berbulu sisik 3-4 mm. Frond tufted setinggi $0,5-1,5 \mathrm{~m}$. Stipe 
panjangnya 5-10 $\mathrm{cm}$. Lamina melintang sempit, panjang $35-70 \mathrm{~cm}$, lebar $12-28 \mathrm{~cm}$, bipinnatifit. Vena 4-6 pasang. (Tjitrosoepomo, 2014).

Asplenium truncatum C. Ditemukan di Hm 0, sebelum sungai. Asplenium hidup epifit pada pohon. Frond Asplenium memiliki panjang $38 \mathrm{~cm}$ dan lebar $4,5 \mathrm{~cm}$. Asplenium memiliki rhizome yang creeping. Bentuk frondnya pinnatus. Sepanjang stipe dan rachis memiliki groove. Lamina pinnatus. Spora dilindungi indusium. Menurut literatur, rhizomenya tegak atau creeping, dictyostelic, dengan sisik clathrate. Stipe matt atau nitidous, hitam, kasar atau abu-abu-hijau, goyah, atau dengan rambut, atau dengan sisik clathrate. Frond sederhana sampai 4-pinnatifid, glabrous, pubescent atau dengan sisik berserakan, vena menyirip atau flabellate. Sori biasanya memanjang, indusium sempit. (Tjitrosoepomo, 2014).

Nephrolepis davallioides Kze. Ditemukan di Hm 0 setelah sungai hidup epifit pada batang pohon. Setelah diamati, panjang $79 \mathrm{~cm}$ dan lebar $26 \mathrm{~cm}$. Rhizome decumbent. Stipe hingga costae bersisik. Pinnatus berlobus pada daun fertil, pinnatus berseling pada daun steril. Venasinya menggarpu. Ciri khas dari Nephrolepis ialah sorus nya berbentuk ginjal (indusium reniform), maka dari itu diberi nama "nephro". Menurut literatur, Nephrolepis memiliki rimpang pendek, tegak, dengan stolon panjang. Daun ber- umbai, suberect untuk melengkung, hingga $4 \mathrm{~m}$ panjang. Memiliki stipe panjang hingga $75 \mathrm{~cm}$, coklat muda, mengkilap, berbentuk lanset, dan bersisik. Lamina pada Nephrolepis berukuran hingga $3,25 \times 0,5 \mathrm{~m}$, berbentuk lanset, venasi menyirip, pinna lebih rendah sedikit berkurang.

Pinna lama petiolate, sempit oblong secara garis besar, miring dasar dan luas cuneate, tidak setara, lonjong puncak ke titik, kedua permukaan tipis diatur dengan rambut putih menit ketika muda, berbulu dengan usia, margin dangkal bergigi (lebih kuat di puncak), yang gerigi sering yang terjadi di pasang, pembuluh darah gratis, berakhir di hidatod mencolok. Rachis pucat coklat, iris set dengan rambut putih kecil dan tersebar pucat sisik coklat.

Sori berindisuium berbentuk ginjal berukuran 1,5 mm, membentuk garis submarginal sepanjang kedua sisi pinnae (Tjitrosoepomo, 2014).

Selaginella opaca Warb. Selaginella opaca ini ditemukan di $\mathrm{Hm} 03$ setelah melewati sungai dan hidup secara terrestrial. Berdasarkan pengamatan, paku ini memiliki rhizome long creeping, berduri, dan memiliki akar adventif. Memiliki stipe yang dipenuhi mikrofil. Lamina berbentuk mikrofil. Spora bertumpuk di ujung mikrofil. Kedudukan mikrofilnya alternate. Menurut literatur, sebagian besar Selaginella memiliki batang berbaring dan sebagian berdiri tegak, bercabang-cabang, menggarpu. Ada yang tumbuhnya membentuk rumpun, ada yang memanjat. Tunasnya dapat mencapai panjang beberapa meter. Pada batang terdapat daundaun kecil yang tersusun dalam garis spiral. Cabang-cabang seringkal mempunyai susunan dorsiventral. Dari 4 baris daun itu yang 2 baris terdiri atas daun-daun yang lebih kecil terdapat pada sisi atas cabang-cabang dan menghadap ke muka. Daun- daun hanya memiliki 1 tulang tengah yang tidak bercabang. Akar-akar keluar dari bagian-bagian batang yang tidak berdaun dinamakan pendukung akar (Akar Adventif). Pada bagian bawah sisi atas daun terdapat suatu sisik yang dinamakan lidah-lidah (ligula). Protalium amat kecil dan mengalami reduksi. (Tjitrosoepomo, 2014).

Huperzia phlegmaria Rothm. Ditemukan di Jalur Ciwalen Hm 06 dan hidup epifit pada batang pohon dan menjuntai ke bawah. Rhizomenya short -creeping. Memiliki stipe yang dipenuhi oleh mikrofil beracabang. Memiliki spora berbentuk strobilus. Menurut literatur, hidup epifit terjumbai dengan panjang 20-45 cm, bercabang-bercabang. Daun lanceolate, panjangnya 9-16 mm dengan lebar 2-3 mm, paling lebar di dekat akar. Daerah fertil berbentuk strobiliform, sangat tajam dibedakan dari dedaunan, panjang 3-13 $\mathrm{cm}$, lebar 1,5-2 mm, 1-3 kali bercabang dikotomisasi; sporophylls \pm ovate, panjang 1,5-2 $\mathrm{mm}$, lebar $1,5 \mathrm{~mm}$, hanya sebagian menutupi sporangia dan biasanya sangat 
sedikit lebih panjang dari lamina. Sporangia dengan lebar $\pm 1,3 \mathrm{~mm}$.

Hymenophyllum sp. Hymenophyllum ini ditemukan di Jalur Ciwalen $\mathrm{Hm} 05$. Hymenophyllum hidup secara epifit pada batang pohon. Rhizomenya short creeping. Memiliki stipe yang berwarna coklat. Percabangannya pinnatus pinnatifid. Memiliki spora di ujung daun. Ciri khas pada paku ini, memeiliki lamina yang transparan karena hanya tersusun oleh selapis sel. Menurut literatur, rhizome merambat, filiform, dengan beberapa trikoma coklat sederhana sampai 0,8 $\mathrm{mm}$. Fronds berjarak 0,3-3 cm; stipe filiform, panjang 6-24 $\mathrm{mm}$. Lamina berbentuk kipas atau oval luas secara garis besar, 15-35x15-24 $\mathrm{mm}$, tidak teratur terbagi menjadi hampir 3pinnatifid dengan sampai 27 lobus margin keseluruhan dengan beberapa. Vena berulang kali bercabang bercabang. Sori pada lobus apeks, panjang 1,5-2,3 $\mathrm{mm}$, berdiameter 1,8 $\mathrm{mm}$ (Tjitrosoepomo, 2014).

Diplazium proliferum Thou. Ditemukan di jalur Ciwalen $\mathrm{Hm}$ 08. Dari hasil pengamatan, Diplazium proliferum memiliki rhizome serabut berwarna coklat. Stipe tebal, berambut dan berwarna hijau kecoklatan. Laminanya bertipe pinnatus pisus berwarna hijau, dengan venasi menjala. Spora atau sorusnya menggarpu berbentuk huruf $\mathrm{V}$, panjang ex induciate. Hidup terestrial. Menurut literatur, rhizome tegak, berdaging bersisik coklat pucat. Frond berumbai (tufted), tinggi 1,5-2,1 m. Lamina oblong-lanceolate, panjang $15-120 \mathrm{~cm}$, lebar $26-44 \mathrm{~cm}$ Venasi anastomosing. Sori berwarna coklat, banyak, sempit, tampak seperti pohon bercabang bersebelahan dari masing-masing sisi pelepah pinnae di setiap area yang dibatasi oleh lobus dengan 7-8 pasang sori per pohon; keseluruhannya memberikan serangkaian garis zig-zag paralel sepanjang pinna dengan tipe indusia linier.

\section{KESIMPULAN}

Berdasarkan pengamatan dengan teknik ditemukan 10 jenis paku (fern) dengan suku yang berbeda-beda. Sepuluh jenis paku yang didapat yaitu Asplenium truncatum C, Diplazium proliferum Thou, Equisetum ramosissimum Desf, Hymenophyllum sp, Didymochlaena truncatula Sm, Huperzia phlegmaria Rothm, Nephrolepis davallioides Kze, Botrychium daucifolium Hook \& Grev, Selaginella opaca Warb, Sphaerosthepanos sp. Dari setiap jenis paku (Fern) memiliki ciri khas (Spot Character) yang dapat dijadikan dasar identifikasi dan dengan mengamati lebih lanjut ciri-ciri yang terdapat pada setiap pakunya. Jika dibandingkan dengan jumlah tumbuhan di wilayah Taman Nasional Gunung Gede Pangrango (TNGGP) jumlah ini berbanding jauh daripada jumlah yang didapat.

\section{UCAPAN TERIMAKASIH}

Terima kasih kami ucapakan kepada Allah SWT yang telah memberikan kemudahan dalam pelaksanaan penelitian tumbuhan paku ini, orang tua serta keluarga yang telah mendukung kami dan telah memberi restu serta izin mengikuti acara Field trip ini serta ucapan terima kasih kami ucapkan kepada dosen kami Bpk. Rizhal Hendi Ristanto, Bpk. Agung Sedayu dan mentor kami Kak Ari Septiyaninsih dan Kak Umi Kulsum yang telah membantu kami, serta para panitia yang membantu kelancaran acara ini dan semua peserta Field trip ini yang sama-sama membantu kegiatan ini. Dan tak lupa kami ucapkan terima kasih kepada pihak Kebun raya Cibodas (KRC) dan Pihak Taman Nasional Gunung Gede Pangrango (TNGGP) yang telah banyak membantu dalam pelaksanaan kegiatan ini.

\section{DAFTAR PUSTAKA}

Holtum RE. 1966. General Key to Malayan Fern dalam Flora of Malaya Vol. II. Fern of Malaya. Goverment Printing Office: Singapore, Hal: 30-37, terj.: Sedayu, A. 2008. Kunci Untuk Marga Paku yang Umum dan Semenanjung Malaya (Kemungkinan Berlaku di Indonesia Barat). Herbarium Jurusan Biologi Universitas Negeri Jakarta.

Humaedi I. 2013. Manajemen wisata pendakian Taman Nasional Gunung Gede Pangrango (TNGGP) Jawa Barat. www.gedepangrango.org 
Kurniawati E. 2016. Manajemen Wisata Pendakian Taman Nasional Gunung Gede Pangrango (TNGGP) Jawa Barat. www.gedepangrango.org

LIPI, Lembaga Biologi Nasional. 1980. Jenis Paku Indonesia. Jakarta: Balai Pustaka.
Tjitrosoepomo G. 2014. Taksonomi Tumbuhan. Yogyakarta: Gadjah Mada University Press.

Sastrapradja, 2000. Jenis-Jenis Tumbuhan Paku. Bogor: LIPI 